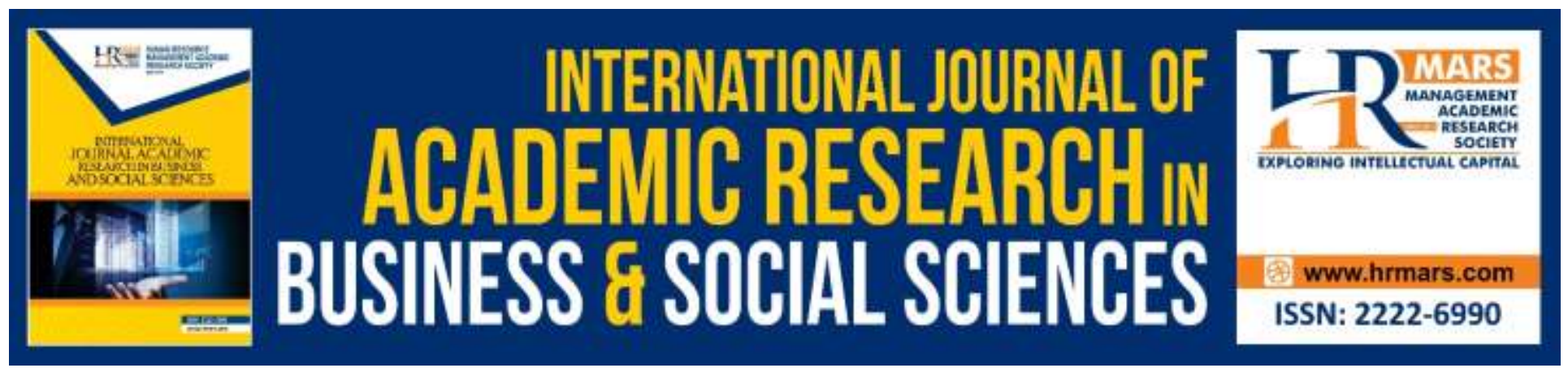

\title{
The Adoption of Ar-Rahnu and Financial Wellbeing of Micro- entrepreneurs in Malaysia
}

Nik Hadiyan Nik Azman, Mohd Zaidi Md Zabri, Tajul Ariffin Masron, Nurhafiza Abdul Kader Malim

To Link this Article: http://dx.doi.org/10.6007/IJARBSS/v10-i6/7259

DOI:10.6007/IJARBSS/v10-i6/7259

Received: 04 April 2020, Revised: 22 May 2020, Accepted: 29 May 2020

Published Online: 02 June 2020

In-Text Citation: (Azman et al., 2020)

To Cite this Article: Azman, N. H. N., Zabri, M. Z. M., Masron, T. A., \& Malim, N. A. K. (2020). The Adoption of ArRahnu and Financial Wellbeing of Micro-entrepreneurs in Malaysia. International Journal of Academic Research in Business and Social Sciences, 10(6), 36-53.

\section{Copyright: (C) 2020 The Author(s)}

Published by Human Resource Management Academic Research Society (www.hrmars.com)

This article is published under the Creative Commons Attribution (CC BY 4.0) license. Anyone may reproduce, distribute, translate and create derivative works of this article (for both commercial and non-commercial purposes), subject to full attribution to the original publication and authors. The full terms of this license may be seen at: http://creativecommons.org/licences/by/4.0/legalcode

Vol. 10, No. 6, 2020, Pg. 36 - 53

Full Terms \& Conditions of access and use can be found at http://hrmars.com/index.php/pages/detail/publication-ethics 


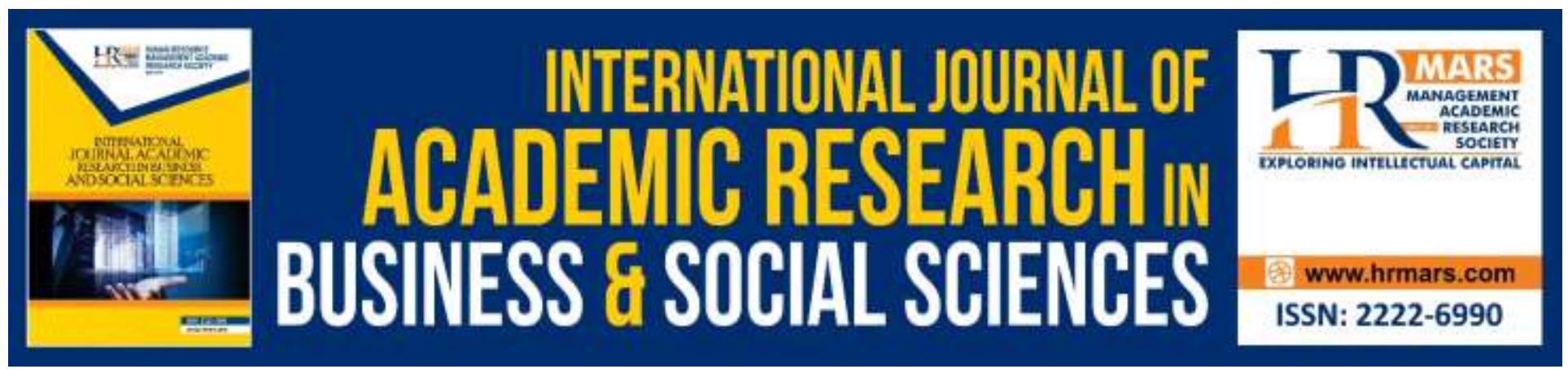

\title{
The Adoption of Ar-Rahnu and Financial Wellbeing of Micro-entrepreneurs in Malaysia
}

\author{
Nik Hadiyan Nik Azmana, Mohd Zaidi Md Zabrib, Tajul Ariffin \\ Masron $^{a}$, Nurhafiza Abdul Kader Malim ${ }^{a}$ \\ aslamic Finance Section, School of Management, Universiti Sains Malaysia, Penang, Malaysia \\ ${ }^{b}$ Department of Finance \& Banking, Faculty of Business and Accountancy, University of Malaya, \\ Kuala Lumpur, Malaysia
}

\begin{abstract}
There is an urgent call for a potential justification on how and to what extent customers (microentrepreneurs) of Ar-Rahnu institutions in Malaysia are successfully driven their living standards from B10 (hardcore poverty) to B40 (low income). This study classified Ar-Rahnu's adoption factors into three categories, namely, Shari'ah governance, uniqueness of Ar-Rahnu, and efficiency. 150 questionnaires were distributed to micro-entrepreneurs that used Ar-Rahnu and analysed using SmartPLS 3.0. Based on the results, it shows that Shari'ah governance has a low correlation and insignificant relationship towards Ar-Rahnu adoption. Stated differently, it means that customers find Shari'ah-compliance requirements not as important and it does not get in their way of getting instant cash from Ar-Rahnu. The other two constructs, namely as uniqueness and efficiency, have positive relationships with Ar-Rahnu adoption. It shows a significant and positive relationship with the ArRahnu financing output. Unlike previous studies within the body of knowledge that mainly focuses on the adoption factors of Ar-Rahnu, this study went a step further by addressing the after-effect or impact of Ar-Rahnu adoption towards customers' wellbeing, especially in terms of financial wellbeing and have found positive results.
\end{abstract}

Keywords: Ar-Rahnu, Financial Wellbeing, Micro-entrepreneurs

\section{Introduction}

The world has seen increased growth in Micro Small Medium Enterprises (MSMEs) since the financial crisis in 2008 (World Bank, 2020) as MSMEs have been active in developing innovative products, create conducive networking services collaboration and upscaling their businesses. Indirectly, by empowering MSMEs, this paper will inevitably work our way towards achieving the United Nation's Sustainable Development Goals (SDGs): SDG \#1 (no poverty), SDG \#2 (zero hunger), SDG \#3 (good health and well-being), SDG \#5 (gender equality), SDG \#8 (promote inclusive and sustainable economic growth, employment and decent work), and SDG \#9 (improve sustainable industrialisation 
INTERNATIONAL JOURNAL OF ACADEMIC RESEARCH IN BUSINESS AND SOCIAL SCIENCES Vol. 10, No. 6, June, 2020, E-ISSN: 2222-6990 @ 2020 HRMARS

and fostering innovation). As a result of empowering MSMEs, the number of MSMEs is increasing $(53 \%)$, and surprisingly, about $47 \%$ out of the total were involved in micro-enterprises (Figure 1 ).

Figure 1.0

Number of MSMEs in Developing Countries (\%)

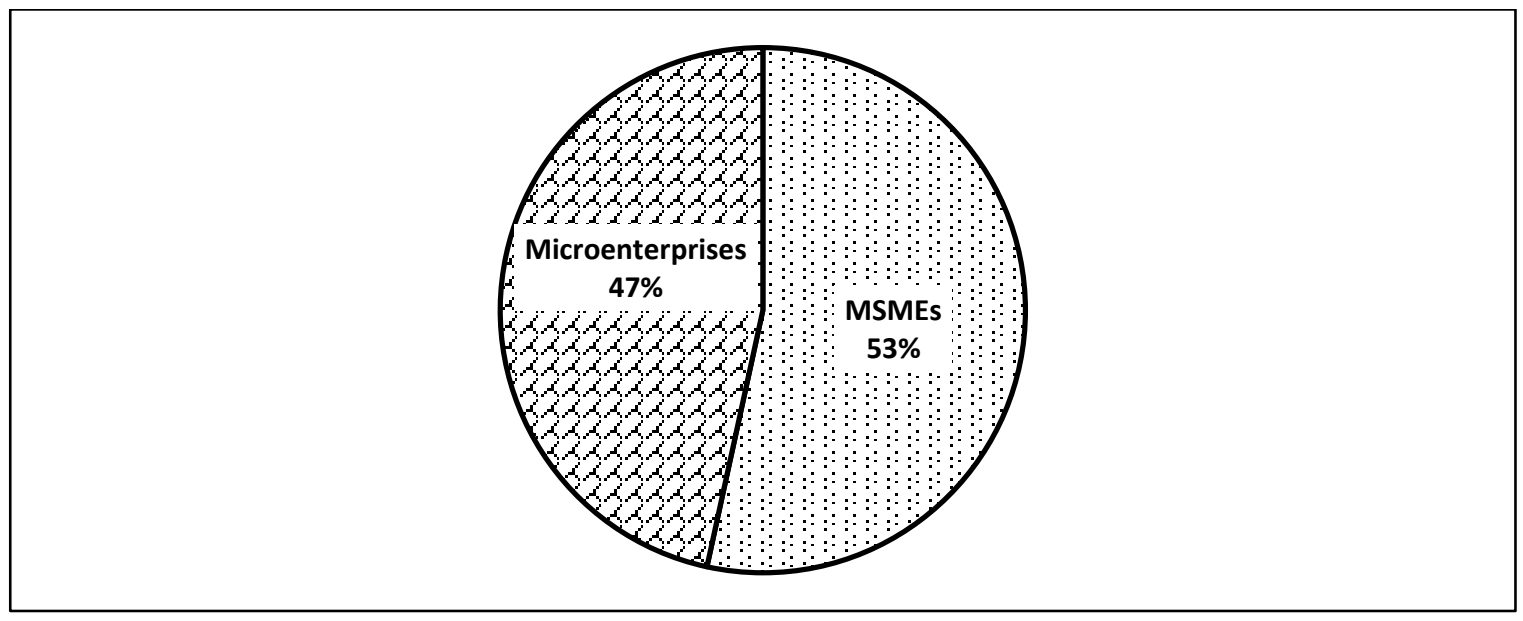

Source: World Bank (2020)

Besides the increasing number of MSMEs, there is a significant challenge that needs to be faced by MSMEs, especially micro-entrepreneurs, which is the shortage of capital or limited access to finance. The financing gap is depicted in Table 1. Due to this gap, the number of entrepreneurs who are applying for micro-financing is on the rise as reported by Bank Negara Malaysia in its 2019 Annual Report. Besides, the Malaysian government has decided to set RM3,000 as the poverty line basis for the urban poor (Zainal Azim et al., 2016) and hitherto, when the number of bottom-line community increases, theoretically, it will directly increase the demand for micro-financing.

Table 1.0

MSMEs Finance Gap in Malaysia (Volume, Million)

\begin{tabular}{ccc|}
\hline No. of MSMEs (Demand) & Current Supply & MSMEs Finance Gap \\
\hline $\mathbf{9 1 , 3 9 0 , 1 1 6 , 7 9 9}$ & $69,935,901,865$ & $21,454,214,934$ \\
\hline
\end{tabular}

Source: International Finance Corporation (2019)

Micro-financial institutions in Malaysia provides cash or capital to the borrowers. Usually, the process of micro-financing only takes about one hour. After one hour, the borrowers can have their money and proceed with their daily business. Microcredit can be offered, often without collateral, to an individual or through group lending. In Malaysia, there are few micro-financing institutions such as Majlis Amanah Rakyat (MARA, established in 1966), Amanah Ikhtiar Malaysia (AIM, est. 1987), Yayasan Pembangunan Ekonomi Islam Malaysia (YaPEIM, est. 1993) and Yayasan Tekun Nasional (TEKUN, est. 1993). ${ }^{1}$ The objective of the micro-financing loans is to assist the poorest in the lowincome family, particularly micro-entrepreneurs.

${ }^{1}$ Majlis Amanah Rakyat (MARA), Tabung Ekonomi Kumpulan Usaha Niaga (TEKUN) and Yayasan Pembangunan Ekonomi Islam Malaysia (YaPEIM) can be literally translated to People's Trust Council, 
INTERNATIONAL JOURNAL OF ACADEMIC RESEARCH IN BUSINESS AND SOCIAL SCIENCES Vol. 10, No. 6, June, 2020, E-ISSN: 2222-6990 @ 2020 HRMARS

Another trend of micro-financing in Malaysia is Ar-Rahnu. These micro-credit schemes are trending owing to several reasons. First, it suits the specific financing requirements of the people in need (Ismail \& Ahmad, 1997; Amin, 2011). Specific financing requirements mean utilisation of funds in a myriad of ways such as financing for wedding ceremonies, home and vehicle purchases, education, and investment. Second, Ar-Rahnu is hugely popular due to its quick service and approval, lower service charges, and simple procedures (Muhamat et al., 2011). Besides, difficulties in getting funds from the formal and commercial financial institutions have been among the main reason for customers to opt for Ar-Rahnu. These difficulties can mainly be attributed to the excessive bureaucracy of the funding agencies and formal financial institutions that tend to take a longer time to disburse the loans (e.g., three to six months) with various documentations. Besides, they impose a rather high cost of borrowing and high legal documentation fees (see Saleh and Ndubisi, 2006; Westover, 2008; Hassan et al., 2011, Zabri, 2012, Darmansyah, 2013, Abbas, Abdul Razak and Saad, 2014).

Nevertheless, Ar-Rahnu is also not without issues and has always been debated by scholars ever since its inception. Among the issues are on Shari'ah governance of Ar-Rahnu (Mulazid, 2012; Rasmin and Markom, 2014; Shah and Yaakob, 2016; Shater et al. 2017), the similarities between ArRahnu charges and conventional pawnshops (Naim, 2004; Abdul Razak, 2011; Yaakob, 2014), the inclusion of Ar-Rahnu as micro-finance products (Mohamed, 1986; Ismail and Ahmad, 1997; Samsudin, 2002; Abdul Khir et al., 2012; Abdullah, 2012; Hisham et al., 2013; Bahari et al., 2015; Azman et al., 2017) and the efficiency of Ar-Rahnu (Samsudin, 2012). As these issues are still being deliberated among scholars, it is highly relevant for this study to review the Ar-Rahnu's acceptance factors despite its popularity. The acceptance factors of Ar-Rahnu have also been examined by scholars such as Amin et al. (2011), Sam et al. (2012), and Azman et al. (2017). Previous studies suggested that customers are still loyal to Ar-Rahnu and continue to patronise Ar-Rahnu services. Several customers believe that Ar-Rahnu is the only option to enhance their living (economically). Therefore, there exists an imperative that besides examining Ar-Rahnu's acceptance factors, we also need to examine the aftereffect of using Ar-Rahnu, especially in the aspect of the financial wellbeing of customers. It is because, previous studies have overlooked the output or impact of Ar-Rahnu adoption towards customers' wellbeing, especially in terms of financing wellbeing. Hence, there is an urgent call for a potential justification on how and to what extent customers of Ar-Rahnu institutions in Malaysia are successfully driven their living standards from B10 (hardcore poor) to B40 (low income).

The organization of this study is as follows. The next section will review past studies on ArRahnu adoption variables and Ar-Rahnu financing's impact on customers' wellbeing. In the proceeding section, this study explains the methodology used and in the fourth section, this study analyses the factors that theoretically and empirically justify the importance of determining the

The Economic Fund for National Entrepreneurs Group and The Malaysian Islamic Economic Development Foundation respectively. 
INTERNATIONAL JOURNAL OF ACADEMIC RESEARCH IN BUSINESS AND SOCIAL SCIENCES

Vol. 10, No. 6, June, 2020, E-ISSN: 2222-6990 @ 2020 HRMARS

financial wellbeing of Ar-Rahnu adoption. Subsequently, a discussion on the results and conclusion section concludes the study.

\section{Literature Review}

\section{Ar-Rahnu and Financing Well-being}

The ultimate objective of Ar-Rahnu institutions is to enhance its customers' financial wellbeing. According to Chapra (2008), Ar-Rahnu could be one of the financial instruments that can ensure individual, society, and economic justice by practising the equitable distribution of income and eradicate poverty. This benefits an individual's well-being by assisting customers with their consumption (bill payments, housing-related expenses, emergency-related expenses, and expenses for ceremonies). Apart from this, Meera (2010) highlights that Ar-Rahnu also could enhance the individual well-being as it increases awareness on wealth management purposes such as saving, starting a new business, expanding the existing business, and buying a house for investment.

Generally, financing wellbeing is defined as having financial security and financial freedom of choice, at present and in the future. In the context of this study, financial wellbeing can be defined as the Ar-Rahnu financing that will affect micro-entrepreneurs in either upscaling or downscaling their businesses, having enough money to cover basic expenses, and have extra money at monthends.

As indicated by Abdul Razak (2011), about 70 percent of the Ar-Rahnu customers are agreeable with the positive role of financing in improving their economic situation. In term of economic wellbeing, Azman et al. (2017), found that Ar-Rahnu benefits women micro-entrepreneurs by helping to expand (increase the branch of business) and diversify (increase the line of product offering of) their businesses. Even though there are other options to obtain cash, yet Ar-Rahnu is preferred by women micro-entrepreneurs as it provides instant cash, operated using simpler procedures, and is easily accessible.

\section{Shari'ah Governance of Ar-Rahnu}

Shari'ah (Islamic jurisprudence) is a sacred law of Islam as it is derived from the Quran and Sunnah. ${ }^{2}$ On the other hand, Shari'ah governance (SG) is a set of institutional and organizational arrangements through which Islamic Financial Institutions (IFI) ensure that there is effective and independent oversight of Shari'ah compliance over the issuance of relevant Shari'ah pronouncements, dissemination of information and an internal Shari'ah compliance review (IFSB, 2018). Based on the given definition, an IFI needs to have a Shari'ah board to review and ensure all financing transactions or procedures (such as products, instruments, operations, practices, management) to comply with Shari'ah (Mansour, 2019; Umar et al., 2018; Azmi et al., 2017; Farook et al., 2011). This Shari'ah compliance practices will directly boost the confidence of the shareholders and the public.

Ar-Rahnu is a Shari'ah-compliant concept. Ar-Rahnu uses the concepts of Wadiah Yad Dhamamah, Qardhul Hassan, and Ujrah in its transaction, indirectly eliminating the elements of Riba

\footnotetext{
${ }^{2}$ Quran is Islamic holy book and Sunnah is the saying, practice, and traditions of Prophet Muhammad (peace be upon him). In addition, two more important sources as ijma' (i.e. consensus among Muslim jurists) and qiyas (i.e. the deduction of legal prescriptions from the Quran or Sunnah by analogical reasoning) are also occasionally applied.
} 
and Gharar (see; Ismail \& Sanusi, 2005; Amin et al., 2007; Sharif et al., 2013). This means that failure to comply with the Shari'ah principles will fail to achieve the objectives of Ar-Rahnu. In this regard, there is a need to ensure the correct application and implementation of the Islamic concepts of Wadiah Yad Dhamamah ${ }^{3}$, Qardhul Hassan ${ }^{4}$, and Ujrah ${ }^{5}$. These Islamic principles will make Islamicbased pawnshops distinguishable from the conventional ones and would be more appealing to customers who are very concerned with Shari'ah-compliance requirements (Ismail \& Sanusi, 2005; Amin et al., 2007). These Islamic contracts benefited customers of Ar-Rahnu in terms of valuing customers' assets adhered to Shari'ah without manipulative tactics (abusive lending). According to the Islamic contracts also, the welfare of the customers is taking care of by Ar-Rahnu. For example, Ar-Rahnu offering loan without interest, low storage fees, and informing customers before lender sell the collateral and excess yield will be given back to customers.

\section{The Uniqueness of Ar-Rahnu}

This study highlights a few features of conventional pawnshops, which differs from Ar-Rahnu. The primary motivation of the conventional pawnshops is profit rather than the welfare of the customers (Ismail \& Ahmad, 1997; Carter \& Skiba, 2013; Mohd Hussin et al., 2016). The key requirement for large profits is the rapid turnover of capital or, in other words, fast redemptions (Whelan, 1979). In contrast, while Ar-Rahnu is also profit-oriented, they are also working towards welfare-improvement by assisting those in need. The differences of conventional pawnshops and Ar-Rahnu have been highlighted by several scholars such as Muhamad et al. (2019), Azim et al. (2016), Zuraini, and Salleh (2014), Naim (2004), Bhatt (2008) and Abdullah (2008). These scholars elucidate on the mechanical differences between conventional pawnshops and Ar-Rahnu. In a similar vein of the conventional pawnshops, the mechanism of Ar-Rahnu also has three stages. There is a lending process, redeeming process, and auctioning process.

During the lending process at conventional pawnshops, the customer must have a valid identification card, which affirms that a customer's age must be 18 years and above. The pawnbroker will not assess the customer's credit risk, such as credit scoring, but focuses on evaluating the collateral's value. The collateral is important during the lending process to determine the amount of loan that can be disbursed. Usually, conventional pawn broking accepts collateral in the form of jewellery and valuable electronic devices. As documented by Carter and Skiba (2013), about 49 percent of pawnshop loans are collateralised with jewellery, with most of the items in the jewellery category consisting of rings, including both men's and women's class and wedding rings. The next most popular category of pledges is televisions and electronics, including satellite dishes, stereos, and CD players. Customers also commonly pawn tools, household items such as small appliances, sporting equipment, guns, musical instruments, and camera equipment (Shabbir, 2019).

\footnotetext{
${ }^{3}$ Wadiah Yad Dhamamah means savings or deposits with guarantee.

${ }^{4}$ Qardhul Hassan is a benevolent loan. The repayment is for the same amount, but customers may pay more than what he/she borrowed so long as it is not predetermined or stated in the contract. 5 Ujrah means fee. The financial charge for using services, or Manfaah (wages, allowance, and commission).
} 
After the pawnbroker accepts the collateral, the fixed interest rate of two percent per month will be imposed on the customer as stated in the Pawnbrokers Act 1972, Section 17(1) (Suhana et al., 2016). The pawnbroker will then issue a pawn ticket as a proof of transaction. The pawn ticket records the customer's particulars such as the customer's name and address, a description of the collateral, the amount lent, the maturity date, and the amount that must be paid to redeem the assets. Usually, the six-month maturity period is given to customers to redeem the collateral. An extension is generally granted, but the customer must pay the previous interest rate first before continuing with the extension period.

Unlike conventional pawnbroking, the customers approach the Ar-Rahnu to place their jewellery under the principle of the Ar-Rahnu contract. Ar-Rahnu gives an interest-free loan to the customers based on the Qard contract. The maximum loan amount offered to the customers is about 70 percent of the gold value. The pledged gold is known as 'Marhum', which is kept by the Ar-Rahnu operator under the principle of Wadiah Yad Dhamamah. At this stage, the customers need to pay for service charges based on the Ujrah principle. Customers paid the service charges during the settlement of the financing. Typically, the service charges imposed by Ar-Rahnu are lower than the 2 percent imposed by conventional pawnshops. During the storage period, the Ar-Rahnu is liable to guarantee the pledged asset in case of damage.

The second stage is the redeeming process. During the redeeming process, the pawnbroker will deliver the pledged items to any person who presents the pawn ticket. If the customer is not able to redeem their pledge items in the specific period given, the pledged items will become the property of the pawnbroker if the pawned value does not exceed RM 200. The pawnbroker can dispose of the pledged items via auction if the value of the pledged items exceeds RM 200 (Pawn Broking Act, 1972). In Ar-Rahnu, during the redeeming process, the customer is required to bring the pawn receipts and pay for the loan plus with the safekeeping fees. If a customer is unable to pay for the loan, the ArRahnu operator allows the customer to apply for an extension for another three months (Bhatt \& Sinnakkannu, 2008). However, if a customer fails to pay within the extension period, the Ar-Rahnu operator has the authority to auction the pledged asset to pay off the loan.

The auctioning process is the final stage. In conventional pawnshops, the auction process will be handled by a licensed auctioneer (Abdul Razak, 2011). Unfortunately, in most cases, the licensed auctioneer usually collaborates with the pawn dealer on the auction-pawned items by valuing the pawned items at meagre prices resulting in a loss for the pawner, earning nothing after the auctioned process (Sulaiman et al., 2014). This can be avoided if the conventional pawnbroker uses proper documentation and is genuine or truthful to the borrower. At the same time, the borrower must also know his/her rights before engaging in such transactions so that they are not facing fraud and coercion. On the other hand, the auction method in Ar-Rahnu, as stated in the Pawnbrokers Act 1972 (Section 18):

'Auction can only be done by a licensed auctioneer. The pawnbroker must inform the pawner by post regarding the date, time and place of auction. An announcement that an auction will be held must be publicized. The pawnbroker 
INTERNATIONAL JOURNAL OF ACADEMIC RESEARCH IN BUSINESS AND SOCIAL SCIENCES Vol. 10, No. 6, June, 2020, E-ISSN: 2222-6990 @ 2020 HRMARS

and borrower can buy the article that is being auctioned. Auctioned articles

become the property of the buyer'.

Before the auctioning process, the Ar-Rahnu operator will send a letter to inform the customer about the auctioning process, i.e. the time, date, and location of the auction. In the case of surplus after the loan has been settled, the excess fund will be returned to the customer. In contrast, in the case of insufficient cash after the auction, the customer needs to pay the balance.

\section{Efficiency of Ar-Rahnu}

The efficiency of Ar-Rahnu institutions is an essential element to be addressed due to the drastic increase in the number of Ar-Rahnu outlets in Malaysia. Since Ar-Rahnu is an alternative to conventional pawn broking, there is a need to measure its effectiveness so that its existence in the financial market can be sustained (Ismail \& Maamor, 2014). Therefore, this study intends to investigate the efficiency of Ar-Rahnu institutions and to link it with the ability to provide funds to the society in need. As discussed by previous studies, few factors can affect the efficiency of $A r-$ Rahnu, namely as Ar-Rahnu outlets' competitors (Yafeh \& Yosha, 2001), size of Ar-Rahnu outlets (Casu and Molyneux, 1998; Souza et al., 2003; Stavarek, 2003; Chang and Chiu, 2006) and financial self-sufficiency (Alufohai, 2006; Chan et al., 2007; Bhuiyan, 2013; Nik Azman et al., 2017).

As mentioned by Yafeh and Yosha (2001), the competition of Ar-Rahnu outlets is one of the factors that affect its efficiency. According to Ismail et al. (2001), the competition will arise when new players see the profitability and sustainability of the Ar-Rahnu market. This could result in a positive and healthy impact as it encourages Ar-Rahnu operators to foster good relations and work harder to gather, retain as well as expanding its customers' base. The competition factor is also being supported by Berger et al. (2001) and Elsas (2005).

Firm size (i.e. the size of Ar-Rahnu outlets) is an essential factor for Ar-Rahnu efficiency towards Ar-Rahnu adoption. Previous studies such as Souza et al. (2003), Stavarek (2003), and Chang and Chiu (2006) found that the positive impact of the outlet size towards efficiency. Stated differently, the larger the outlet size, the larger the number of customers the outlet has. This indirectly will benefit the Ar-Rahnu institutions in terms of economies of scale as the larger Ar-Rahnu institutions can offer cheaper services to the customers.

Financial self-sufficiency is also one of the indicators for Ar-Rahnu efficiency. Financial selfsufficiency indicates whether their revenue is sufficient to cover both direct costs (financing costs, provisions for loan losses and operating expenses) and indirect costs (adjusted cost of capital) (Maamor \& Ismail, 2010; Brau \& Woller, 2004). In short, financial self-sufficiency reflects an entity that can meet its current needs without compromising the ability to cover for their future needs (Bhuiyan, 2013). Besides, Bhuiyan (2013) also clarifies financial self-sufficiency as an individual's ability to cope recover from external stress and shocks, while enhancing the capabilities for the present and future. Financial self-sufficiency can be measured by the number of customers per operating costs. In other words, the efficiency of Ar-Rahnu can be measured via loan disbursement at a very minimum cost. 
INTERNATIONAL JOURNAL OF ACADEMIC RESEARCH IN BUSINESS AND SOCIAL SCIENCES

Vol. 10, No. 6, June, 2020, E-ISSN: 2222-6990 @ 2020 HRMARS

\section{Methodology}

This research uses quantitative methods in acquiring data and information through a survey from October to December 2019. The population for this study is Ar-Rahnu customers who are directly involved with Ar-Rahnu institutions. To obtain insights from Ar-Rahnu users, especially those from B40 (low income) and M40 (middle income), the location for this research is in Penang and Kedah, two states located in the northern region of Peninsular Malaysia. In conducting the survey, the sampling method is based on purposive sampling as the simple random sampling would not be able to achieve the study objective. In order to determine the sample size of this study, a power analysis was used to calculate the sample size. Therefore, this study used power analysis (G*Power) to determine the sample size at the required 95\% confidence level (Figure 2).

Figure 2.0

G*Power Sample Size

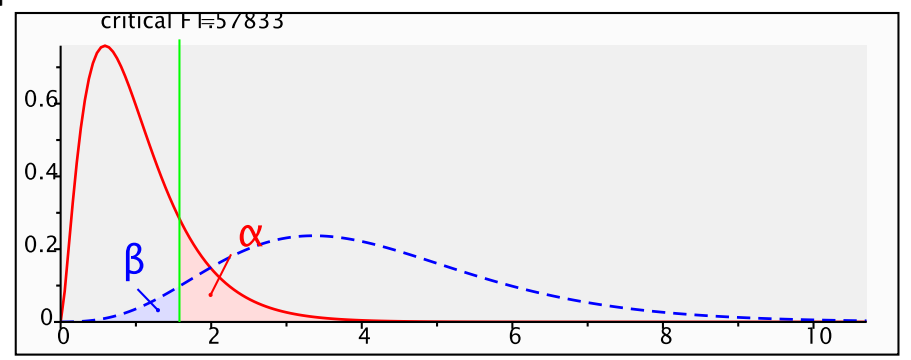

According to $G^{*}$ Power of sample size, the sample is considered enough as the minimum sample size required is only 100 respondents. In fact, as the rule of thumb used by Hair et al. (2010), 100 is considered as sufficient size for a small sample. The primary data then be analysed by using IBM SPSS for preliminary analysis and Structural Equation Modelling (SEM) by using Smart PLS to test the hypothesised relationships. As documented by Ullman (2006), SEM also allows a set of relations between one or more independent variables (IVs), either continuous or discrete, and one or more dependent variables (DVs), either continuous or discrete, to be examined.

Figure 3.0

Ar-Rahnu's Adoption and Financial Wellbeing

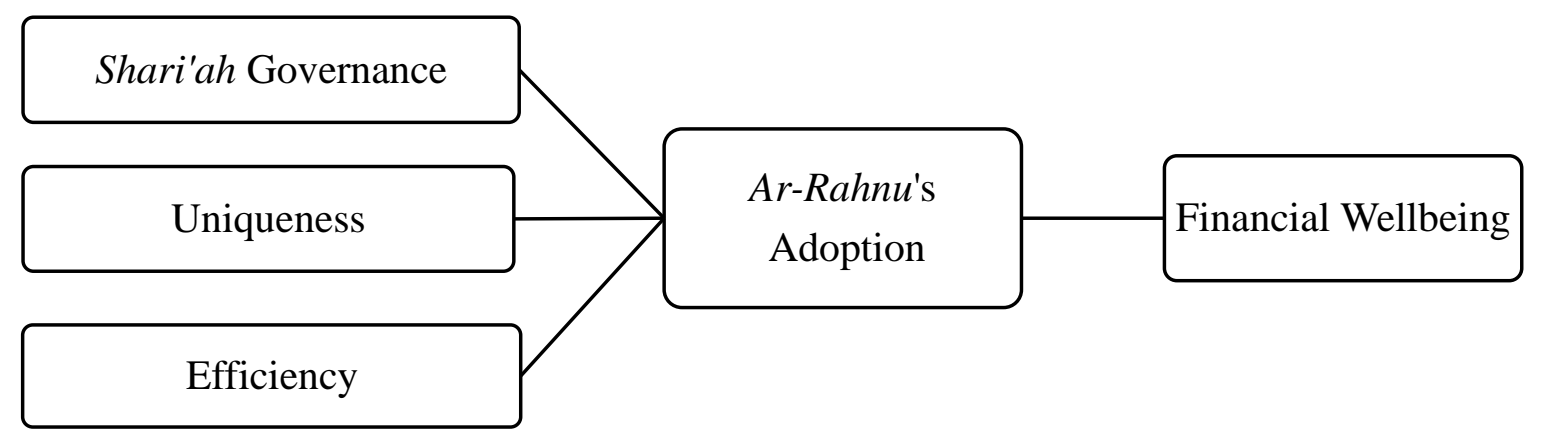


INTERNATIONAL JOURNAL OF ACADEMIC RESEARCH IN BUSINESS AND SOCIAL SCIENCES

Vol. 10, No. 6, June, 2020, E-ISSN: 2222-6990 @ 2020 HRMARS

\section{Analysis and Results}

The questionnaires were distributed to 150 respondents. However, only 125 questionnaires were useable. Based on Table 2.0, slightly more than three quarters (68\%) of the respondents are female. Most respondents are married (64\%), and four respondents (4\%) are single mothers. Malay is the highest ethnicity among the respondents (90\%). In terms of age, a significant proportion of respondents are in the age range of $26-35$ years old (51\%), followed by $36-45$ years old (34\%), $46-55$ years old (13\%), and 56-65 years old (2\%). Stated differently, the utilisation of Ar-Rahnu is relevant and wide-ranging across all age groups. Besides, in terms of education level, users of Ar-Rahnu are predominantly having at least a secondary level of education (98\%). Surprisingly, while collecting the data, several Ar-Rahnu users even have postgraduate degrees (Master and PhD) (12\%). Nevertheless, not surprisingly, almost half of the respondents (45\%) are of the RM 1001 and RM 2000 income bracket and thus, putting them as an urban poor according to the Department of Statistics, Malaysia (Table 1).

Table 2.0

Sample Characteristics

\begin{tabular}{llr}
\hline Demographic Respondent & & Frequency [\%] \\
\hline Gender & Male & $32[32.0]$ \\
Marital Status & Female & $68[68.0]$ \\
& Married & $64[64.0]$ \\
& Single & $32[32.0]$ \\
Ethnicity & Single Mother & $4[4.0]$ \\
& Malay & $90[90.0]$ \\
Age & Chinese & $7[7.0]$ \\
& Indian & $3[3.0]$ \\
& $26-35$ & $51[51.0]$ \\
& $36-45$ & $34[34.0]$ \\
Education & $46-55$ & $13[13.0]$ \\
& $56-65$ & $2[2.0]$ \\
& No Formal Education & $3[3.0]$ \\
& Primary School & $4[4.0]$ \\
& Secondary School & $48[48.0]$ \\
& Diploma & $24[24.0]$ \\
Salary & Bachelor's degree & $9[9.0]$ \\
& Postgraduate Degree & $12[12.0]$ \\
& $1001-2000$ & $45[45.0]$ \\
& $2001-3000$ & $32[32.0]$ \\
& $3001-4000$ & $14[14.0]$ \\
& $4001-5000$ & $5[5.0]$ \\
& $5001-6000$ & $4[4.0]$ \\
\hline
\end{tabular}

Note. $\mathrm{N}=100$. Figure in [ ] denotes $\%$ of total.

This study then further reviewed the measurement model. As indicated in Table 3.0, according to Hair et al. (2010), convergent validity is the degree to which indicators of a specific construct 
INTERNATIONAL JOURNAL OF ACADEMIC RESEARCH IN BUSINESS AND SOCIAL SCIENCES

Vol. 10, No. 6, June, 2020, E-ISSN: 2222-6990 @ 2020 HRMARS

converge or share a high proportion of variance in common. This study assesses the convergent validity by following indicators suggested by Hair et al. (2017). Hair et al. (2017) proposed to have more than 0.5 for average extracted variance (AVE), cut off value for factor loading is 0.5 and all composite reliability (CR) is greater than 0.7 . The loadings for all items are 0.5 and above, and the item loadings of less than 0.5 were subsequently dropped. However, it does not exceed the $20 \%$ threshold as recommended by Hair et al. (2010). All in all, AVE more than 0.5, and CR is greater than 0.7 after the process of items deletion. At this stage, it is concluded that the construct meets both reliability and convergent validities.

Table 3.0

Measurement Model

\begin{tabular}{|c|c|c|c|c|}
\hline Construct & Item & Loading & CR & AVE \\
\hline \multirow[t]{7}{*}{ Shari'ah Governance } & SG1 & 0.759 & 0.894 & 0.547 \\
\hline & SG2 & 0.750 & & \\
\hline & SG3 & 0.763 & & \\
\hline & SG4 & 0.773 & & \\
\hline & SG5 & 0.748 & & \\
\hline & SG6 & 0.721 & & \\
\hline & SG7 & 0.654 & & \\
\hline \multirow[t]{7}{*}{ Uniqueness } & UN2 & 0.696 & 0.884 & 0.522 \\
\hline & UN4 & 0.750 & & \\
\hline & UN5 & 0.686 & & \\
\hline & UN6 & 0.810 & & \\
\hline & UN7 & 0.715 & & \\
\hline & UN8 & 0.661 & & \\
\hline & UN9 & 0.730 & & \\
\hline \multirow[t]{8}{*}{ Efficiency } & EF2 & 0.569 & 0.907 & 0.553 \\
\hline & EF3 & 0.815 & & \\
\hline & $\mathrm{EF} 4$ & 0.661 & & \\
\hline & EF5 & 0.785 & & \\
\hline & EF6 & 0.843 & & \\
\hline & EF7 & 0.817 & & \\
\hline & EF8 & 0.773 & & \\
\hline & EF9 & 0.636 & & \\
\hline \multirow[t]{9}{*}{ Ar-Rahnu's Adoption } & AA1 & 0.636 & 0.933 & 0.537 \\
\hline & AA10 & 0.765 & & \\
\hline & AA11 & 0.742 & & \\
\hline & AA12 & 0.683 & & \\
\hline & AA2 & 0.731 & & \\
\hline & AA3 & 0.792 & & \\
\hline & AA4 & 0.728 & & \\
\hline & AA5 & 0.717 & & \\
\hline & AA6 & 0.702 & & \\
\hline
\end{tabular}




\begin{tabular}{lllll}
\hline & AA7 & 0.779 & & \\
AA8 & 0.764 & & \\
Financial Wellbeing & AA9 & 0.742 & & \\
& AFO1 & 0.822 & & \\
AFO2 & 0.775 & & \\
AFO3 & 0.824 & \\
AFO4 & 0.808 & \\
AFO5 & 0.835 & \\
AFO6 & 0.847 & \\
AFO8 & 0.778 & \\
\hline
\end{tabular}

Note. UN1, UN3, EF1, EF10, AFO10, AFO7, and AFO9 were deleted due to low loading.

Subsequently, the study assessed the model's discriminant validity. Ideally, items should load more strongly on their constructs than on other constructs in the model. Apart from that, the average variance (AVE) shared between each construct, and its measures should be greater than the variance shared between the construct, and its measures should be greater than the variance shared between the construct and other constructs (Fornell \& Larker, 1981). Table 4.0 exhibits the study's discriminant validity.

Table 4.0

Discriminant Validity

\begin{tabular}{lccccc}
\hline & $\mathbf{1}$ & $\mathbf{2}$ & $\mathbf{3}$ & $\mathbf{4}$ & $\mathbf{5}$ \\
\hline 1. Ar-Rahnu Adoption & 0.733 & & & & \\
2. Uniqueness & 0.492 & 0.723 & & & \\
3. Efficiency & 0.589 & 0.387 & 0.743 & & \\
4. Financial Wellbeing & 0.742 & 0.383 & 0.393 & 0.813 & \\
5. Shari'ah Governance & 0.333 & 0.554 & 0.530 & 0.134 & 0.739 \\
\hline
\end{tabular}

After examining the validity and reliability of the model, it is important to assess the direct hypotheses suggested in the study. This study developed four (4) hypotheses between the construct. In order to test the significance level, $t$-statistics for all paths are generated using SmartPLS 3.0 bootstrapping function. Based on Table 5.0, three relationships are found to have $t$-value $>2.33$, and thus, making these relationships significant at 0.01 level of significance. One relationship is found not significant $(\mathrm{H} 1)$. Among all, the predictor of Efficiency $(\beta=0.525, p<0.01)$ shows the strongest relationship towards Ar-Rahnu adoption. The $\mathrm{R}^{2}$ value of 0.425 is above the 0.26 value, as suggested by Cohen (1988), which indicates a substantial model. Nevertheless, Shari'ah governance $(\beta=-0.152$, $\mathrm{p}>0.10$ ) shows an insignificant relationship towards Ar-Rahnu adoption. Therefore, only $\mathrm{H} 2$ and $\mathrm{H} 3$ are supported while the study failed to reject $\mathrm{H} 1$. Besides, this study further assessed the relationship between Ar-Rahnu adoption and financing wellbeing $(\beta=0.742, p<0.01)$. It represents a significant relationship, demonstrated by the $\mathrm{R}^{2}$ value of 0.546 or $54.6 \%$, which is higher than the recommended value of 0.26 (Table 5). Thus, $\mathrm{H} 4$ is supported. 
INTERNATIONAL JOURNAL OF ACADEMIC RESEARCH IN BUSINESS AND SOCIAL SCIENCES Vol. 10, No. 6, June, 2020, E-ISSN: 2222-6990 @ 2020 HRMARS

Table 5.0

Structural Model

\begin{tabular}{|c|c|c|c|c|c|c|c|c|c|}
\hline & & $\begin{array}{l}\text { Std. } \\
\text { Beta }\end{array}$ & $\begin{array}{l}\text { Std. } \\
\text { Error }\end{array}$ & $\begin{array}{c}\text { t- } \\
\text { value }\end{array}$ & $\begin{array}{c}\mathrm{p}- \\
\text { valu } \\
\mathrm{e}\end{array}$ & Decision & $\begin{array}{c}\mathrm{BCl} \\
\mathrm{LL}\end{array}$ & $\begin{array}{l}\mathrm{BCl} \\
\mathrm{UL}\end{array}$ & $f^{2}$ \\
\hline \multirow[t]{3}{*}{ H1 } & Shari'ah & - & 0.123 & 1.24 & 0.10 & Rejected & - & 0.00 & 0.02 \\
\hline & Governance $\rightarrow$ Ar- & 0.15 & & & 8 & & 0.37 & & 4 \\
\hline & Rahnu Adoption & 2 & & & & & & & \\
\hline \multirow[t]{2}{*}{$\mathrm{H} 2$} & Uniqueness $\rightarrow$ & 0.37 & 0.088 & 4.258 & 0.00 & Supporte & 0.22 & 0.518 & 0.17 \\
\hline & Ar-Rahnu Adoption & 3 & & & 0 & d & 9 & & 0 \\
\hline \multirow[t]{2}{*}{ H3 } & Efficiency $\rightarrow$ Ar- & 0.52 & 0.096 & 5.446 & 0.00 & Supporte & 0.32 & 0.653 & 0.35 \\
\hline & Rahnu Adoption & 5 & & & 0 & $\mathrm{~d}$ & 8 & & 0 \\
\hline \multirow[t]{2}{*}{ H4 } & Ar-Rahnu Adoption & 0.74 & 0.063 & 11.84 & 0.00 & Supporte & 0.62 & 0.831 & 1.22 \\
\hline & $\begin{array}{l}\rightarrow \text { Financial } \\
\text { Wellbeing }\end{array}$ & 2 & & 9 & 0 & $d$ & 6 & & 6 \\
\hline
\end{tabular}

The study then proceeded to assess the effect size $\left(\mathrm{f}^{2}\right)$. As mentioned by Sullivan and Fein (2012), the $p$-value only tells readers on the existence of the effect size, but it does not reveal the size of the effect. Therefore, it is important to report both the substantive significance (effect size) and statistical significance ( $p$-value). To measure the effect size, Cohen (1988) suggested the following guideline to measure effect size: 0.02 (small effect), 0.15 (medium effect), and 0.35 (large effect). Based on Table 5.0, both efficiency (0.350) and Ar-Rahnu's adoption (1.226) factors have a large effect size, whereas uniqueness has a medium effect (0.170) and Shari'ah governance has a small effect $(0.024)$ in producing $R^{2}$. Stated differently, the omission of these two constructs will give a substantive impact on the model. It also highlights the importance of these two constructs, and therefore, future study should include these two constructs in measuring financial wellbeing.

\section{Discussion}

Ar-Rahnu is getting greater recognition especially among the Malay-Muslim community due to its ability to assist those in need, especially from the bottom line of the community, such as the lowincome group who faces insufficient cash, has emergency needs and is excluded from the mainstream financial institutions (Razak, 2011; Ismail \& Ahmad, 1997). There are many Ar-Rahnu providers in Malaysia operated by different institutions, either operationalised by banking or non-banking financial institutions. Even though there are other options to obtain cash, yet Ar-Rahnu is the most preferred by customers as it provides instant cash, has simple procedures, and is easily accessible. Although the relationship between acceptance and adoption of Ar-Rahnu has been investigated in previous studies by Amin et al. (2007); Mohamad et al. (2014); Salleh (2014), and Yahaya et al. (2019), evidence on the link between the adoption of Ar-Rahnu and financing output is still scarce. There is a limited number of previous studies investigating the financing outcomes which involve individuals, society, and the overall economy, with the exception of Salleh (2014), Nik Azman et al. (2018), and Yahaya et al. (2019). Besides, it is important to note that married respondents greatly used Ar-Rahnu than single or widows. This might be due to married respondents requiring more expenses, not only for business purposes, but also to cater to family expenses, child-rearing demands, and high costs of living (Johnson and Johnson, 1998; Schrader, 2000 and Abdul Razak, 2011). 
INTERNATIONAL JOURNAL OF ACADEMIC RESEARCH IN BUSINESS AND SOCIAL SCIENCES Vol. 10, No. 6, June, 2020, E-ISSN: 2222-6990 @ 2020 HRMARS

The finding of this study has both theoretical and managerial implications. Theoretically, the overwhelming majority of the studies believed Ar-Rahnu is an enabling tool for the poor and bottomline community. Several studies, such as Abdul Razak (2011) highlighted Ar-Rahnu users consist of the poor level of education. On the contrary, Sharif et al. (2013) mentioned that customers with strong educational background would possess better economic and financial circumstances, and hence, has little to no need for instant cash through Ar-Rahnu as they could easily access other types of formal financial assistance to meet their needs. Notwithstanding, this study departs slightly from previous studies as almost half of the respondents are having a strong educational background (diploma, undergraduate, and postgraduate degrees). Stated differently, Ar-Rahnu is no longer exclusively serving the niche market of poor and uneducated people that it was once touted to be. More worryingly, it may also mean that Ar-Rahnu may no longer be focusing on the poor, who usually has a higher default risk profile. Apart from that, it is equally interesting to note that about one-third of the respondents are men. It can also be inferred that the acceptance and awareness of Ar-Rahnu utilization have reached male population and indirectly disputes the argument by Nik Azman et al. (2017) that men would not consider Ar-Rahnu financing as they may feel disgraced associating themselves with an institution that was more popularly associated with women in Malaysia.

There is a need to ensure the correct operationalisation of the Islamic concepts of Wadiah Yad Dhamamah, Qardhul Hassan, and Ujrah at Ar-Rahnu's institutions (Ismail \& Sanusi, 2005; Amin et al. 2011; Yahaya et al. 2019). These Islamic principles will make Islamic-based pawnshops distinguishable from the conventional ones and would be more appealing to customers who are very concerned with Shari'ah-compliance requirements. Surprisingly, however, instead of strict adherence to the Shari'ah principles, the finding shows that Shari'ah governance has a negative relationship with Ar-Rahnu's adoption. This is in stark contrast to the previous literature (i.e., Omer 1992; Metwally, 1996; Amin 2011; Abdul Hamid et al., 2014; Loon Koe et al., 2012; Nik Azman et al., 2016) which mentioned the positive relationship between religious obligation and the use of ArRahnu. At this point, one can only speculate. And the authors reckon that there might be two extreme, possible explanations to this finding. First, the customers are so familiar with the Ar-Rahnu operations that they no longer view Shari'ah Governance as important as it was once used to matter to them. In short, it has become second nature to them that even the complicated Arabic contractual terms and operationalisations, which are pervasively used in non-Arabic speaking countries such as Malaysia are no longer an issue. Second, the customers are somewhat worried about Shari'ah Governance (or lack thereof) by Ar-Rahnu providers. For example, there have been well-documented cases of mismanagement and misappropriation of funds by one of the largest Ar-Rahnu providers in Malaysia.

Consistent with earlier expectations, the other two constructs of this study, the uniqueness of Ar-Rahnu and the efficiency of Ar-Rahnu show a significant positive relationship towards the adoption of Ar-Rahnu. In terms of the uniqueness of Ar-Rahnu, customers might be aware of the different processes and procedures applied by Ar-Rahnu. A potential explanation for efficiency could be that these respondents have enjoyed a good experience and are comfortable in using Ar-Rahnu. A good experience may relate to the quick response to customer demands, always ensuring the security and confidentiality of each transaction and giving fair treatment to all irrespective of the customer's race, religion or creed despite it being rooted deeply in Shari'ah. Besides, Ar-Rahnu 
officers always fulfil the promise of its services promptly and also try to minimise work errors as well as issuing receipt(s) after each transaction. These value-added services and personal bonds build personal attachment as well as fostering a relationship with Ar-Rahnu's providers. The results of this study are in agreement with previous research such as Mansor et al. (2014), who supported the link between efficiency and use of Ar-Rahnu. Besides, Muhamad et al. (2019) highlighted the importance of respecting customer's trust by maintaining a reliable and trustworthy service. Respecting customers' trust and understanding how the customer views service quality is essential in ensuring an effective relationship with customers (Mohamad et al., 2014; Mansor et al., 2014; Bedi, 2010; Abdullah, 2010; Oliver, 1994).

\section{Conclusion}

Ar-Rahnu is well-known for its easy access by the marginalised segment of society. Consequently, it is no wonder that it has been a mainstay and provide a positive impact on its users. The literature has been highlighting the positive effects of Ar-Rahnu upon its users (Amin, 2011; Azman et al., 2016; Hussin et al., 2016; Yahaya et al., 2018; \& Muhamad et al., 2019). Notwithstanding, there has been little attempt in investigating the 'how' or 'to what extent' questions. This study, therefore, included this wellbeing factor in objectively measuring whether Ar-Rahnu achieves what it originally sets out to achieve-improving the wellbeing of its users. The users find that Ar-Rahnu has a positive impact on their socio-economic lives. Be it in their children's education (C1), debt settlement (C4), reducing unemployment (C7), and social problems that usually comes with it (C8), and more importantly, help to their businesses' breadth and intensify their depth (C9 and C10). These positive findings then can be added into the contextual contribution to the body of knowledge-especially in empirically investigating the positive effect of Ar-Rahnu have on the lives of its users. Besides, this kind of positive findings can also be highlighted by Ar-Rahnu operators in its marketing effort, emphasising the positive socio-economic impact of Ar-Rahnu and instead of merely focusing on the competitive rates as compared to the conventional pawnshops or its Shari'ah-compliancy aspect.

Notwithstanding, this study only investigates a direct relationship without involving mediating or moderating variables (indirect effects), therefore for future research; this study proposes to explore the moderating or mediating effect of self-inclusion (voluntary and involuntary basis). Voluntary users of Ar-Rahnu can be defined as customers who voluntarily partake in Ar-Rahnu as a medium of financing. This might be due to insufficient income, discrimination, rotating capital, and simpler procedures. On the other hand, the involuntary users are known as customers who are against using Ar-Rahnu in the first place but have no other viable option except Ar-Rahnu. This might be due to reasons such as being blacklisted or declared as bankrupts or excluded from the formal financial service providers. This involuntary group should be given comprehensive attention as it might be categorised as a group that has a greater inclination to default in servicing their payments.

\section{Acknowledgement}

The first author would like to thank Universiti Sains Malaysia for granting a Bridging Incentive Grant No.304.PMGT.6316410. 
INTERNATIONAL JOURNAL OF ACADEMIC RESEARCH IN BUSINESS AND SOCIAL SCIENCES

Vol. 10, No. 6, June, 2020, E-ISSN: 2222-6990 @ 2020 HRMARS

\section{References}

Abbas, K., Razak, D. A., \& Saad, N. M. (2014), "The perception of micro-entrepreneurs and petty traders on conventional and Islamic microfinance: a case study of Pakistan", Journal of Islamic Finance, Vol. 3 No. 1, pp. 038-048.

Abdul-Razak, A. (2011), "Economic and Religious Significance of the Islamic and Conventional Pawnbroking in Malaysia: Behavioural and Perception Analysis", Doctoral dissertation, Durham University.

Alufohai, G. O. (2006), "Sustainability of Farm Credit delivery by Cooperatives and NGOs in Edo and Delta states, Nigeria", Educational Research and Reviews, Vol. 1 No. 8, pp. 262.

Amin, H. (2011), "Modelling Ar-Rahnu use in Eastern Malaysia: Perspectives of Muslimah", Journal of Islamic Economics, Banking and Finance, Vol. 7 No.3, pp. 63-76.

Amin, H., Chong, R., Dahlan, H., \& Supinah, R. (2007). An Ar-Rahnu shop acceptance model (ARSAM). Labuan E-journal of Muamalat and Society, 1, 82-94.

Azman, N. H. N., \& Kassim, S. H. (2017), “Ar-Rahnu as a Source of Financial Sustainability for Women Micro-Entrepreneurs in Malaysia", Journal of Islamic Monetary Economics and Finance, Vol. 2, No. 2, pp. 221-250.

Azli, R. M., Palil, M. R., \& Nor, M. S. (2016), “Benefits-Sacrifices Exchange (BSX) in Islamic pawn broking transaction: An exploratory factor analysis", International Journal of Business, Economics and Law, Vol. 10 No. 1, pp. 38-52

Azmi, A., Non, N., \& Ab Aziz, N. (2017), "Challenges to Shari'ah equity screening, from Shari'ah scholars' perspective", International Journal of Islamic and Middle Eastern Finance and Management, Vol. 10 No. 2, pp. 229-242.

Bahari, N. F., Safii, Z., Ahmad, N. W., Fisal, S., \& Shahar, W. S. S. (2015), "A Reviews on the Regulation and Conflicting Issues of Ar-Rahnu Operation in Malaysia", in Proceeding of the 2nd International Conference on Management and Muamalah, 16-17 November 2015, BangiPutrajaya Hotel, Malaysia.

Balqis, Y. (2014), "Faktor-faktor yang mempengaruhi kesedaran usahawan kecil Muslim terhadap skim Ar-Rahnu (pajak gadai Islam)", Doctoral dissertation, Universiti Utara Malaysia.

Bhatt, P., \& Sinnakkannu, J. (2008), “Ar-Rahnu (Islamic pawning broking) opportunities and challenges in Malaysia", paper presented 6th International Islamic Finance Conference (pp. 255-268).

Bhuiyan, A. B. (2013), "Microcredit and sustainable livelihood: an empirical study of Islamic and conventional credit on the development of human capital of the borrowers in Bangladesh", Journal of Economic Cooperation \& Development, Vol. 34 No. 3, pp.101.

Campbell, D. T., \& Fiske, D. W. (1959), "Convergent and discriminant validation by the multitraitmultimethod matrix", Psychological Bulletin, Vol. 56 No. 2, pp. 81.

Carter, S. P., \& Skiba, P. M. (2012), "Pawnshops, behavioral economics, and self-regulation", Review of Banking and Financial. Law, Vol. 32 No. 1, pp. 193.

Casu, B., \& Molyneux, P. (2003), "A comparative study of efficiency in European banking”, Applied Economics, Vol. 35, No.17, 1865-1876.

Chapra, M. U. (2008), "The Islamic Vision of Development", Thoughts on Economics, The Quarterly Journal of Islamic Economics Research Bureau (Bangladesh), Vol. 18 No. 3, pp. 7-38.

Cohen, J. (1988), "Statistical power analysis for the behavioral sciences", Hillsdale, NJ: Erlbaum, pp.

Pellegrina, D. L. (2011), "Microfinance and investment: A comparison with bank and informal lending", World Development, Vol. 39, No. 6, pp. 882-897. 
INTERNATIONAL JOURNAL OF ACADEMIC RESEARCH IN BUSINESS AND SOCIAL SCIENCES

Vol. 10, No. 6, June, 2020, E-ISSN: 2222-6990 @ 2020 HRMARS

Darmansyah, A., Nasution, R. A., Sutardi, A., \& Zen, T. S. (2013), “Microfinance Institutions (MFIs) Profit Sharing Pattern for the Development of Micro and Small Enterprises (MSEs) in Indonesia", Sains Humanika, Vol. 64 No. 2.

Farook, S., Hassan, K. M., \& Lanis, R. (2011), "Determinants of corporate social responsibility disclosure: The case of Islamic banks", Journal of Islamic Accounting and Business Research, Vol. 2, No.2, pp. 114-141.

Fornell, C., \& Larker, D. (1981), "Structural equation modeling and regression: guidelines for research practice", Journal of Marketing Research, Vol. 18 No.1, pp. 39-50.

Ismail, G. A., \& Ahmad, Z. N. (1997), "Pawnshop as an instrument of microenterprise credit in Malaysia", International Journal of Social Economics, Vol. 24, No. 11, pp. 1343-1352.

Hamid, M. A., Rahman, I. A., \& Halim, A. N. A. (2014), "Factors affecting the acceptance on Ar-Rahnu (Islamic based pawn broking): a case study of Islamic banking in Malaysia", The Macrotheme Review, Vol. 3 No. 4, pp. 22-35.

Holmbeck, G. N. (1997), "Toward terminological, conceptual, and statistical clarity in the study of mediators and moderators: Examples from the child-clinical and paediatric psychology literature", Journal of Consulting and Clinical Psychology, Vol. 65 No.4, pp. 599.

Hussin, M. Y. M., Zulkeply, M. A., Razak, A. A., \& Muhammad, F. (2016), “ Marketing Mixed Strategy and Its Relationship in Islamic Pawning Products Selection at Ar-Rahnu YaPEIM", International Journal of Academic Research in Business and Social Sciences, Vol. 6 No. 11, pp. 175-190.

Ismail, A. G., \& Sanusi, N. A. (2005), "A framework for regulating pawnshops: Why do, what area and Syariah view", in Proceedings of Malaysian Finance Association (MFA)'s 7th Annual Conference, Universiti Teknologi MARA, pp. 9-10.

Khir, M. F., Badri, M. B., \& Hussain, L. (2013), "Critical Appraisa of The Rahn-Based Islamic Microcredit Facility From Shari'ah Perspective”, ISRA International Journal of Islamic Finance, Vol. 7 No. 3, pp. 221-231.

Maamor, S., \& Ismail, A. G. (2010), "The Ar-Rahnu efficiency and its determinants", Journal of Islamic Economics, Banking and Finance, Vol. 6 No. 1, pp. 105-126.

Mansour, I. H. F. (2019), "Customers' perceptions of selection criteria used by Islamic bank customers in Sudan: The importance of Shari'ah compliance. Journal of Research in Emerging Markets, Vol. 1 No. 4, pp. 20-32.

Meera, A. K. M. (2002), The Islamic Gold Dinar, Pelanduk Publications, Kuala Lumpur.

Mohamed, R. (1986), "The role of Pawnbrokers as non-institutional creditors in Malaysia", Kajian Ekonomi Malaysia, Vol. 22 No. 2, pp. 30-39.

Naim, M. A. (2004), "Sistem gadaian Islam", Islamiyyat: The International Journal of Islamic Studies, Vol. 26 No.2, pp. 39-57.

Muhamat, A. A., Rosly, H. E., \& Jaafar, M. N. (2011), "The non-muslims response towards Ar-Rahnu (Islamic pawn broking) services: An Empirical study on the Ar Rahnu clients of Klang Valley, Malaysia", in Humanities, Science and Engineering (CHUSER), 2011 IEEE Colloquium on (pp. 574579). IEEE.

Muhamad, H., San, O. T., Katan, M. B. H., \& Ni, S. W. (2019), "Factors That Influence the Customers' Perception of Ar-Rahnu (Islamic Pawn Broking Product) in Selangor, Malaysia", International Journal of Academic Research in Accounting, Finance and Management Sciences, Vol. 9 No. 2, pp. 126-137. 
INTERNATIONAL JOURNAL OF ACADEMIC RESEARCH IN BUSINESS AND SOCIAL SCIENCES

Vol. 10, No. 6, June, 2020, E-ISSN: 2222-6990 @ 2020 HRMARS

Ridhwan, M. A. A. (2012), Introduction to Islamic institutions in economics and finance, USIM Publisher, Bandar Baru Nilai.

Mulazid, A. S. (2012), "Kedudukan sistem pegadaian syariah dalam sistem hukum nasional di Indonesia.", Innovatio, Vol. 11, No. 2, pp. 1-23

Azman, N. H., Kassim, S., \& Adeyemi, A. A. (2016), "Role of Ar-Rahnu as Micro-Credit Instrument in Achieving Financial Self-Sufficiency among Women Micro-Entrepreneurs", Intellectual Discourse, Vol. 24 (Special Issue), pp. 365-385.

Rasmin, N. H., \& Markom, R. (2014), “Ar-Rahnu Governance Laws in Malaysia: An Analysis in Banks and Non-Banks Financial Institutions", in International Conference of Global Islamic Studies, pp. 116-27.

Saleh, A. S., \& Ndubisi, N. O. (2006), "An evaluation of SME development in Malaysia”, International review of business research papers, Vol. 2 No. 1, pp. 1-14.

Saunders, M. L., Lewis, P., \& Thornhill, A. (2009). Research methods for business students, 4.

Shater, A. F. M., Hatta, M. F. M., \& Kamis, M. S. (2017), "The Attainment of Classical Rulings of AlRahn Within The Contemporary Islamic Pawn Broking In Malaysia", ASEAN Comparative Education Research Journal on Islam and Civilization (ACER-J), Vol. 1, No. 2, pp. 33-52.

Sieber, S. D. (1973), "The integration of fieldwork and survey methods", American Journal of Sociology, Vol. 78, No. 6, pp. 1335-1359.

Suhana, M., Sham, R., Jaffar, H. H., Latif, R. A., Zaharum, Z., Abidin, R. A. Z., \& Mohamad, W. M. W. (2016), "The Acceptance of Ar-Rahnu Scheme Among Rural Population", in Regional Conference on Science, Technology and Social Sciences, 2014, Springer, Singapore, pp. 663673.

Sulaiman, N. S. H., Kassim, S. F., Alzoubi, I., Ashaboul, K., \& Abidin, M. Z. (2014), "The comparison between Ar-Rahnu and conventional pawn broking", Global Business and Economics Research Journal, Vol. 3 No. 5, pp. 57-65.

Sullivan, G. M., \& Feinn, R. (2012), "Using effect size-or why the P-value is not enough", Journal of Graduate Medical Education, Vol. 4 No. 3, pp. 279-282.

Ullman, J. B. (2006). "Structural equation modeling: Reviewing the basics and moving forward", Journal of Personality Assessment, Vol. 87, No. 1, pp. 35-50.

Umar, Z., Shahzad, S. J. H., Ferrer, R., \& Jareño, F. (2018), "Does Shari'ah compliance make interest rate sensitivity of Islamic equities lower? An industry level analysis under different market states", Applied Economics, Vol. 50 No. 42, pp. 4500-4521.

Westover, J. (2008), "The record of microfinance: The effectiveness/ineffectiveness of microfinance programs as a means of alleviating poverty", Electronic Journal of Sociology, Vol. 12 No. 1, pp. 1-8.

Whelan, T. S. (1979). "The Pawnshop in China: Based on Yang Chao-Y u's Chung-kuo tien-tang yeh", In Michigan Abstracts of Chinese and Japanese Works on Chinese History (No. 6).

Yafeh, Y., \& Yosha, O. (2001), "Industrial organization of financial systems and strategic use of relationship banking", Review of Finance, Vol. 5 No. 1-2, pp. 63-78.

Yahaya, S., \& Bahari, Z. (2018), "Level of Acceptance of Muslim Small-Scale Entrepreneurs in Kelantan towards Ar-Rahnu", International Journal of Academic Research in Business and Social Sciences, Vol. 8, No.5, pp. 848-867. 